\title{
Analisis Ketidaklengkapan Dokumen Rekam Medis Pada Kasus Rawat Inap di RSUD Patut Patuh Patju Gerung
}

\author{
${\text { Ahmad Maliki }{ }^{1 *}, \text { Saimi }^{2)} \text {, Heru Purnama }}^{2)}$ \\ Email: malikibin212@hotmail.com \\ 1) Mahasiswa Prodi D3 Rekam Medik dan Informasi Kesehatan UNIQHBA \\ 2) Prodi D3 Rekam Medik dan Informasi Kesehatan UNIQHBA
}

\begin{abstract}
ABSTRAK
Tujuan umum penelitian ini adalah untuk mengetahui ketidaklengkapan dokumen rekam medis rawat ianp di RSUD Patut Patuh Patju Gerung tahun 2017. Sampel penelitian ini adalah sebagian dari unsur populasi yaitu sebanyak 86 berkas dan disajikan dalam bentuk check list Hasil penelitian menunjukkan adanya ketidaklengkapan dalam pengisian data identitas yaitu $84,83 \%$ lengkap dan $15,17 \%$ tidak lengkap, Rata-rata ketidaklengkapan pengisian data klinis yaitu $55,36 \%$ lengkap dan 22,0\% tidak lengkap. Rata-rata ketidaklengkapan hasil penunjang yaitu 32,13\% lengkap dan 8,5\% tidak lengkap. Untuk itu sosialisasi tentang pengisian formulir dan kedisiplinan petugas dalam mengisi formulir rawat inap harus lebih di tingkatkan kembali.
\end{abstract}

Kata kunci: Ketidaklengkapan, data klinik, data identitas, formulir penunjang

\begin{abstract}
The purpose of this study is to investigate the uncomplete medical records documents in Patut Patuh Patju Hospital in 2017. The sample has 86 files and presented in the check list form. The result of the study shows the existence of the uncomplete documents in the data identities $84,83 \%$ complete and $15,17 \%$ uncomplete. The mean of the uncomplete clinical record is $22 \%$ while the complete record is $55,36 \%$. Meanwhile, the uncomplete records of support file form is $8,5 \%$ and $32,13 \%$ is complete. This study concludes that the hospital needs to improve its medical records staff competence to produce decent documents.
\end{abstract}

Keywords: Uncomplete, clinical record, identities record, support file

\section{A. LATAR BELAKANG}

Manajemen pelayanan Rekam Medis dan Informasi Kesehatan adalah kegiatan menjaga, memelihara dan melayani rekam medis baik secara manual maupun elektronik sampai menyajikan informasi kesehatan di Rumah Sakit, Praktik dokter Klinik, asuransi kesehatan, fasilitas pelayanan kesehatan, dan lainnya yang menyelenggarakan pelayanan kesehatan dan menjaga rekaman[1]. Rekam medis adalah dokumen penting tiap - tiap rumah sakit maupun layanan kesehatan lainnya yang berisikan catatan mengenai identitas pasien, pemeriksaan, pengobatan, tindakan, dan pelayanan lain[2].

Rekam Medis memiliki arti luas, tidak hanya pada kegiatan pencatatan tetapi juga memiliki pengertian sebagai suatu sistem penyelenggaraan instalasi. Kegiatan pencatatan adalah suatu bentuk aktivitas yang tercantum dalam uraian tugas unit - unit Rekam Medis[3]. Dokumen rekam medis dikatakan lengkap apabila memenuhi indikator dalam kelangkapan pengisian, keakuratan, tepat waktu, sehingga dapat di percaya dan lengkap maka perlu dilakukan tinjauan kelengkapannya. Apabila dokumen rekam medis belum lengkap setelah pasien selesai pelayanan 
atau perawatan dengan batas waktu pelengkapan dokumen rekam medis 48 jam dapat di kategorikan sebagai IMR (Incomplete Medical Record) sedangkan dokumen rekam medis yang belum lengkap setelah melebihi masa pelengkapan dari masing-masing unit pelayanan dengan batas lebih dari 14 hari maka dokumen rekam medis dikategorikan DMR (Delinquent Medical Record)[4]. Berdasarkan studi pendahuluan awal di di RSUD Patut Patuh Patju Gerung, diperoleh hasil bahwa adanya dokumen yang tidak lengkap sehingga dikategorikan DMR. Bangsal perawatan yang diteliti berjumlah 60 bangsal, dimana dari 60 bangsal tersebut terdapat DRM yang kurang lengkap dalam pengisian diagnosa ahir sebanyak 9 berkas yakni $15 \%$,tidak lengkapnya hasil penunjang sebanyak 11 berkas yakni $18,4 \%$,tidak lengkapnya data administratif sebanyak 25 berkas yakni 41,6\%,dan tidak adanya tanda tangan dokter sebanyak 15 berkas yakni $25 \%$. Berdasarkan hasil dari studi pendahuluan awal tersebut, penelitian ini bertujuan untuk menganalisa kasus ketidaklengkapan dokumen rekam medis pada kasus rawat inap di RSUD Patut Patuh Patju Gerung.

\section{B. METODE PENELITIAN}

Berdasarkan uraian di atas, maka desain penelitian yang sesuai untuk penelitian ini adalah metode studi kasus. Alasan penetapan metode ini dikarenakan adanya isu yang kompleks mengenai adanya penyimpangan dari kewajaran. Kasus penyimpangan yang dimaksud adalah adanya ketidaklengkapan dokumen yang diteliti. Penelitian ini berlokasi di ruang Rekam Medis bagian Assembling RSUD Patut patuh Patju Gerung. Sementara itu, waktu penelitian dilaksanakan pada Agustus 2017. Populasi dalam penelitian berupa berkas Rekam Medis pasien rawat inap selama 1 bulan yang berjumlah 600 berkas di unit rekam medis RSUD Patut Patuh Patju Gerung. Sementara itu, untuk menentukan ukuran sampel dari suatu populasi dapat di gunakan rumus Sovin[5]. Berdasarkan rumus tersebut, ditemukan jumlah sampel sebesar 86 berkas rekam medis DMR.

1. Definisi Operasional

Tabel 1. Definisi Operasional

\begin{tabular}{|c|c|c|c|c|c|c|}
\hline No & Variabel & Definisi & Cara Ukur & Alat Ukur & Indikator & Hasil \\
\hline 1 & $\begin{array}{l}\text { Formulir } \\
\text { Persetujua } \\
\text { n Umum }\end{array}$ & $\begin{array}{lr}\text { Formulir persetujuan } \\
\text { umum adalah } \\
\text { merupakan lembar } \\
\text { berkas rekam medis } \\
\text { yang isinya } \\
\text { merupakan } \\
\text { persetujuan bahwa } \\
\text { pasien setuju untuk } \\
\text { mendapatkan } \\
\text { pelayanan rawat inap }\end{array}$ & \multirow{3}{*}{$\begin{array}{l}\text { Telaah pada } \\
\text { formulir } \\
\text { persetujuan } \\
\text { umum } \\
\text {,resume } \\
\text { medis dan } \\
\text { formulir hasil } \\
\text { penunjang } \\
\text { yang ada pada } \\
\text { berkas rekam } \\
\text { medis } \\
\text { berdasarkan } \\
\text { prosedur } \\
\text { tetap } \\
\text { pengisian dan } \\
\text { pengembalia } \\
\text { n dokumen } \\
\text { rekam medis }\end{array}$} & \multirow[t]{3}{*}{$\begin{array}{l}\text { Lembar } \\
\text { checklist }\end{array}$} & \multirow[t]{3}{*}{$\begin{array}{l}\text { Lengkap } \\
\text { / Tidak } \\
\text { lengkap }\end{array}$} & \multirow{3}{*}{$\begin{array}{l}\text { Lengkap } \\
\text { apabila } \\
\text { formulir } \\
\text { terisi } \\
\text { lengkap } \\
\text { dan penuh } \\
\text { / Tidak } \\
\text { lengkap } \\
\text { apabila } \\
\text { formulir } \\
\text { tidak terisi } \\
\text { lengkap } \\
\text { Baik dari } \\
\text { data social } \\
\text { maupun } \\
\text { data klinis }\end{array}$} \\
\hline 2 & $\begin{array}{l}\text { Formulir } \\
\text { Resume } \\
\text { Medis }\end{array}$ & $\begin{array}{l}\text { Resume medis adalah } \\
\text { ringkasan pelayanan } \\
\text { selama perawatan } \\
\text { hingga pasien keluar } \\
\text { dari rumah sakit }\end{array}$ & & & & \\
\hline 3 & $\begin{array}{l}\text { Formulir } \\
\text { Hasil } \\
\text { Penunjang }\end{array}$ & $\begin{array}{l}\text { Hasil penunjang } \\
\text { adalah data mengenai } \\
\text { pasien untuk } \\
\text { membantu dokter } \\
\text { dalam pemeriksaan } \\
\text { fisik meliputi seluruh } \\
\text { organ tubuh pasien }\end{array}$ & & & & \\
\hline
\end{tabular}




\section{Pengumpulan Data}

a. Wawancara

Pada penelitian ini dilakukan wawancara langsung kepada petugas petugas administrasi berkas rekam medis rawat inap dan petugas assembling yang akan melakukan analisa kelengkapan dokumen rekam medis.

\section{b. Observasi/pengamatan.}

Pengamatan pada penelitian ini adalah pengamatan terhadap kelengkapan berkas rekam medis dengan menggunakan instrument ceklist.

\section{HASIL DAN PEMBAHASAN}

1. Identifikasi Ketidaklengkapan pengisian Dokumen Rekam Medis Rawat Inap

a. Ketidaklengkapan pengisian data administratif pasien pada formulir persetujuan umum.

Berdasarkan hasil pengolahan ceklist didapatkan tingkat kelengkapan data administratif pada formullir persetujuan umum pasien rawat inap dapat dilihat pada tabel dibawah ini. Pengisian item nama pasien yang lengkap $83,7 \%$ dan yang tidak lengkap $16,2 \%$, item alamat yang lengkap $86,0 \%$ dan yang tidak lengkap $13,9 \%$, item jenis kelamin yang lengkap $86,0 \%$ dan yang tidak lengkap $13,9 \%$, item umur yang lengkap $84,8 \%$ dan yang tidak lengkap $15,1 \%$, item penanggung jawab yang lengkap $75,5 \%$ dan yang tidak lengkap $24,4 \%$, item tanda tangan yang lengkap 93,0\% dan yang tidak lengkap $6,9 \%$

Tabel 2. Kelengkapan data administratif pada fomulir persetujuan umum.

\begin{tabular}{|l|l|l|l|l|l|l|l|}
\hline No & Data Sosial & Lengkap & $\begin{array}{l}\% \\
\text { Lengkap }\end{array}$ & $\begin{array}{l}\text { Tidak } \\
\text { Lengkap }\end{array}$ & $\begin{array}{l}\% \text { Tidak } \\
\text { Lengkap }\end{array}$ & $\begin{array}{l}\text { Tidak } \\
\text { Berlaku }\end{array}$ & $\begin{array}{l}\% \text { Tidak } \\
\text { Berlaku }\end{array}$ \\
\hline 1 & Nama & 72 & $83,7 \%$ & 14 & $16,2 \%$ & 0 & 0 \\
\hline 2 & Alamat & 74 & $86 \%$ & 12 & $13,9 \%$ & 0 & 0 \\
\hline 3 & $\begin{array}{l}\text { Jenis } \\
\text { Kelamin }\end{array}$ & 74 & $86 \%$ & 12 & $13,9 \%$ & 0 & 0 \\
\hline 4 & Umur & 73 & $84,4 \%$ & 13 & $15,1 \%$ & 0 & 0 \\
\hline 5 & $\begin{array}{l}\text { Penaggung } \\
\text { Jawab }\end{array}$ & 65 & $75,5 \%$ & 21 & $24,4 \%$ & 0 & 0 \\
\hline 6 & $\begin{array}{l}\text { Tanda } \\
\text { Tangan }\end{array}$ & 80 & $93 \%$ & 0 & 0 & 0 & 0 \\
\hline
\end{tabular}

b. Ketidaklengkapan pengisian data klinis pada formulir resume medis pasien rawat inap

Berdasarkan hasil pengolahan ceklist didapatkan tingkat kelengkapan data klinis pada formullir resume medis pasien rawat inap dapat dilihat pada tabel dibawah ini. Pengisian item Anamnesa yang lengkap $77,9 \%$ dan yang tidak lengkap 22,0\%, item tindakan pembedahan yang lengkap 31,3\% yang tidak lengkap $6,9 \%$, dan tidak berlaku $61,6 \%$, item diagnose yang langkap $56,9 \%$ dan yang tidak lengkap $37,2 \%$.

Tabel 3. Kelengkapan pengisian Data Klinis Pada Resume Medis

\begin{tabular}{|l|l|l|l|l|l|l|l|}
\hline No & Data Klinis & Lengkap & $\begin{array}{l}\% \\
\text { Lengkap }\end{array}$ & $\begin{array}{l}\text { Tidak } \\
\text { Lengkap }\end{array}$ & $\begin{array}{l}\% \text { Tidak } \\
\text { Lengkap }\end{array}$ & $\begin{array}{l}\text { Tidak } \\
\text { Berlaku }\end{array}$ & $\begin{array}{l}\% \text { Tidak } \\
\text { Berlaku }\end{array}$ \\
\hline 1 & Anamnesa & 67 & $77,9 \%$ & 19 & $22 \%$ & 0 & 0 \\
\hline 2 & $\begin{array}{l}\text { Tindakan } \\
\text { Medis }\end{array}$ & 27 & $31,3 \%$ & 6 & $6,9 \%$ & 53 & $61,6 \%$ \\
\hline 3 & Diagnosa & 49 & $56,9 \%$ & 32 & $37 \%$ & 0 & 0 \\
\hline
\end{tabular}

c. Ketidaklengkapan rekam medis berdasarkan formulir data hasil penunjang

Berdasarkan hasil pengolahan ceklist

pengisian didapatkan tingkat kelengkapan data hasil penunjang medis pada formullir penunjang pasien rawat inap dapat dilihat pada tabel dibawah ini. Item 
laboratorium yang lengkap 47,6\%, yang tidak lengkap $25,5 \%$,dan tidak berlaku $26,7 \%$, item radiologi yang lengkap $46,5 \%$ yang tidak lengkap $12,7 \%$, dan yang tidak berlaku 40,6\%, item konsultasi gizi yang lengkap 2,3\%, dan tidak berlaku 97,6\%.

Tabel 4. Kelengkapan data klinis pada formulir hasil penunjang

\begin{tabular}{|l|l|l|l|l|l|l|l|}
\hline No & Penunjang & Lengkap & $\begin{array}{l}\% \\
\text { Lengkap }\end{array}$ & $\begin{array}{l}\text { Tidak } \\
\text { Lengkap }\end{array}$ & $\begin{array}{l}\% \text { Tidak } \\
\text { Lengkap }\end{array}$ & $\begin{array}{l}\text { Tidak } \\
\text { Berlaku }\end{array}$ & $\begin{array}{l}\% \text { Tidak } \\
\text { Berlaku }\end{array}$ \\
\hline 1 & Laboratorium & 41 & $47,6 \%$ & 22 & $25,5 \%$ & 23 & $26,7 \%$ \\
\hline 2 & Radiologi & 40 & $46,5 \%$ & 11 & $12,7 \%$ & 35 & $40,6 \%$ \\
\hline 3 & $\begin{array}{l}\text { Konsultasi } \\
\text { Gizi }\end{array}$ & 2 & $2,3 \%$ & 0 & 0 & 84 & $97,6 \%$ \\
\hline
\end{tabular}

2. Pembahasan

\section{a. Identifikasi Kelengkapan Pengisian Data Administratif Pasien Rawat Inap Pada Formulir Persetujuan Umum.}

Persentase pengisian data identitas pasien pada item nama terisi lengkap sebanyak $83,7 \%$ dan pengisan tidak terisi sebanyak $16,2 \%$. Tingginya Persentase pengisian tidak terisi tersebut dikarenakan karena kurang telitinya petugas rekam medis dalam mengidentifikasi data identitas pasien, dan mengganggap tulisan nama yang ada pada sampul berkas rekam medis sudah bisa mewakili kelengkapan pengisian formulir-formulir rekam medis. Sistem penamaan dalam pelayanan medis yaitu tata cara penulisan nama pasien yang bertujuan untuk membedakan satu pasien dengan pasien yang lain dan untuk memudahkan dalam pengindeksan kartu indeks utama pasien (KIUP). Oleh karna itu jika nama pasien tidak terisi maka proses pengidentifikasian akan sulit dilakukan dan proses pencarian dokumen rekam medis akan menjadi sulit apabila sewaktu-waktu terjadinya loose shit atau formulir rekam medis keluar dari map induknya.

Persentase pengisian data identitas pada item jenis kelamin yaitu pengisian terisi sebesar $86,0 \%$ dan pengisian tidak terisi sebanyak $13,9 \%$. Jenis kelamin adalah suatu sifat atau keadaan yang menyatakan pria atau wanita. jenis kelamin merupakan salah satu yang dapat menyebabkan perbedaan kejadian pada pria dan wanita. Dalam hal perbedaan kejadian penyakit, penulisan jenis kelamin harus juga diperhatikan karna akan berpengaruh pada kelancaran proses input data untuk rekam medis yang sudah menggunakan system komputerisasi. Persentase pengisian data identitas pada item umur yaitu pengisian terisi sebesar $84,8 \%$, dan pengisian tidak terisi sebesar $15,1 \%$. Umur merupakan salah satu item yang dapat mempermudah petugas dalam proses pengidentifikasian pasien. penulisan umur secara detail pada formulir rekam medis akan sangat berpengaruh terhadap pelayanan kesehatan pasien, terutama didalam bidang kefarmasian, dikarenakan umur dapat menentukan dosis obat yang harus diberikan kepada pasien. dalam studi epidemiologi, umur sebagai salah satu sifat karakteristik tentang orang yang merupakan variable yang cukup penting karena cukup banyak penyakit ditemukan dengan berbagai variasi frekuensi yang disebabkan oleh umur.

Persentase pengisian data identitas pada item alamat yaitu pengisian terisi sebesar $86,0 \%$, dan pengisian tidak terisi sebesar 13,9\%. Tingginya angka ketidaklengkapan pengisian alamat ini juga di sebabkan karna petugas medis maupun non medis masih menganggap penulisan alamat pada sampul berkas 
rekam medis sudah bisa mewakili formulir-formulir yang ada pada berkas rekam medis. Penulisan alamat secara lengkap akan sangat berpengaruh terhadap proses input data dan pencarian data pasien apabila rekam medis tersebut sudah menggunakan system komputerisasi. Persentase pengisian data identitas pada item penanggung jawab pasien yaitu pengisian terisi sebesar $75,5 \%$, dan pengisian tidak terisi sebesar $24,4 \%$. Selain data pasien diperlukan juga data identitas penanggung jawab pasien pada beberapa formulir rekam medis seperti persetuaan rawat inap dan persetujuan tindakan medis. Karena persetujuan dari pihak pasien harus diisi secara lengkap dan benar sesuai dengan aturan tetap yang sudah dibuat secara konsisten.

Persentase pengisian data identitas pada item tanda tangan yaitu pengisian sebesar $93,0 \%$, dan pengisian tidak terisi sebesar $6,9 \%$, Tanda tangan berarti "tanda" atau Paraf merupakan tulisan tangan atau goresan tinta dari tangan, kadang-kadang diberi gaya tulisan tertentu dari nama seseorang atau tanda identifikasi lainnya yang ditulis pada dokumen sebagai suatu sebuah bukti dari identitas dan kemauan. Adanya angka ketidaklengkapan pengisian tanda tangan disebabkan karna adanya petugas medis dan non medis yang belum mengetahui desain formulir secara lengkap, sehingga pada saat pengisian banyak kolom tanda tangan yang tidak terisi. Berdasarkan hasil penelitian yang dilakukan, maka jumlah item identitas yang lengkap adalah $84,83 \%$, dan tidak lengkap $15,17 \%$, ketidaktelitian petugas rekam medis dalam mengisi dan mengecek ulang, merupakan salah satu penyebab terjadinya ketidaklengkapan berkas rekam medis pasien rawat inap. Pengisian item identifikasi pada formulir persetujuan umum termasuk data administratif sebagai informasi demografi haruslah diisi secara lengkap karna jika tidak diisi berakibat tidak dapat menginformasikan identitas pasien sebagai basis data statistik, penelitian dan sumber perencanaan rumah sakit atau organisasi pelayanan kesehatan[6].

Pendapat tersebut juga dikuatkan dengan Permenkes RI[2], bahwa setiap pencatatan ke dalam rekam medis harus dibubuhi nama, waktu, tanda tangan dokter, dokter gigi, atau tenaga kesehatan tertentu yang memberikan pelayanan kesehatan secara langsung. Menurut Joint Commission International (JCI) Standar akreditasi rumah sakit, untuk memperbaiki proses identifikasi, dikembangkanlah bersama suatu kebijakan atau prosedur. Kebijakan atau prosedur itu setidaknya memerlukan pengidentifikasian pasien, seperti nama pasien, nomor identifikasi pasien dan tanggal lahir pasien atau umur pasien atau item yang lain. Tujuan dari kebijakan tersebut adalah untuk mengidentifikasi pasien dengan benar sebagai orang yang akan diberi layanan atau pengobatan tertentu dan untuk mencocokan layanan atau perawatan dengan individu tersebut.

\section{b. Identifikasi Ketidaklengkapan Pengisian Data Klinis, Dan Tindakan Pada Formulir Resume Medis Pasien Rawat Inap.}

Persentase pengisian data klinis pada item anamnesis yaitu pengisian sebesar $77,9 \%$, dan pengisian tidak terisi sebesar $22,0 \%$ diagnosis masuk memberikan gambaran tentang bagaimana pengobatan yang seharusnya dilakukan oleh seorang dokter. Dengan adanya diagnosis masuk akan memberikan dokter kemudahan dalam memberikan diagnosis saat ini dan pengobatan yang semestinya diberikan kepada pasien. Menurut Hatta[6], keluhan utama/anamnesis merupakan sifat dan lamanya gejala yang menyebabkan pasien mencari bantuan medis sesuai dengan apa yang dikatakan 
pasien. Oleh karena itu, keluhan utama berfungsi untuk mempertegas alasan diperlukannya pengobatan medis selanjutnya oleh petugas kesehatan.

Persentase pengisian data klinis pada item tindakan pembedahan yaitu pengisian sebesar $31,3 \%$, pengisian tidak terisi sebesar $6,9 \%$, dan tidak berlaku $61,6 \%$. adanya angka ketidaklengkapan pada formulir tindakan pembedahan disebabkan oleh kurang telitinya petugas medis khususnya di ruang oprasi dalam melengkapi formulir persetujuan tindakan pembedahan, laporan operasi,dan anastesi sebelum dilakukan tindakan karena setiap tindakan medis yang mengandung resiko cukup besar mangharuskan adanya persetujuan tertulis yang ditandatangani oleh pasien, setelah sebelumnya pasien itu memperoleh informasi yang cukup kuat tentang perlunya tindakan medis yang bersangkutan serta resiko yang bersangkutan dengannya[7].

Persentase pengisian data klinis pada item diagnosis yaitu pengisian sebesar $56,9 \%$, pengisian tidak terisi sebanyak $37,2 \%$. Angka ketidaklengkapan disebabkan oleh banyak dari berkas rekam medis tidak diisi oleh dokter yang menjadi DPJP,dan diisi oleh dokter pengganti. diagnosis adalah hasil dari evaluasi dan itu mencerminkan temuan. jika item diagnosis tidak terisi maka pelayanan seperti penentuan kode penyakit akan menjadi terhambat, dan tentunya akan berpengaruh terhadap proses klaim asuransi kesehatan seperti halnya program BPJS yang mengguanakan indikator kode diagnosis dalam menghitung tanggungan biaya pasien. selain itu apabila diagnosis tidak terisi lengkap akan mengakibatkan penyakit yang diderita pasien tidak dapat diidentifikasi dengan tepat serta dapat menimbulkan kerugian baik bagi pasien maupun bagi rumah sakit.

Berdasarkan hasil penelitian yang dilakukan, maka jumlah item data klinis yang lengkap adalah 55,36\%, tidak lengkap 22,0\%,tidak berlaku $22.64 \%$. faktor pengetahuan dan kurangnya sosialisasi adalah salah satu faktor utama yang menjadi penyebab adanya beberapa formulir data klinis menjadi tidak lengkap. Data klinis merupakan segala data tentang riwayat penyakit, hasil pemeriksaan fisik, diagnosis, pengobatan serta hasilnya, laporan dokter, perawat, hasil penunjang dsb. Data-data ini merupakan data yang bersifat rahasia (confidential) sehingga tidak dapat dibuka kepada pihak ketiga tanpa izin dari pasien yang bersangkutan kecuali jika ada alasan lain berdasarkan peraturan atau perundang-undangan yang memaksa dibukanya informasi tersebut. Hal tersebut juga di kuatkan dengan Permenkes 296 tahun 2008 setiap tindakan konsultasi yang dilakukan terhadap pasien pengisiannya selambatlambatnya 1x24 jam[2].

\section{c. Identifikasi Ketidaklengkapan Pengisian Data Pada Formulir Hasil Penunjang Medis Pasien Rawat Inap}

Persentase pengisian data hasil penunjang pada item laboratorium yaitu pengisian sebesar $47,6 \%$, pengisian tidak terisi sebesar $25,5 \%$, dan tidak berlaku sebesar $26,7 \%$. Tingginya angka ketidak lengkapan pengisian hasil laboratorium disebabkan karna hasil penunjang tidak di satukan langsung dengan induk dokumen rekam medis sehingga pada waktu analisis kelengkapan berkas rekam medis oleh petugas distribusi tidak bisa terlaksanakan. Dengan lengkapnya pengisian hasil penunjang laboratorium, juga akan berpengaruh terhadap proses pengklaiman pasien asuransi,karna bias sebagai penunjang penagakan suatu diagnosis tertentu.

Persentase pengisian data hasil penunjang pada item radiologi yaitu pengisian sebesar $46,5 \%$, pengisian tidak 
terisi sebesar $12,7 \%$,dan tidak berlaku sebesar $40,6 \%$. Dengan adanya angka ketidaklengkapan pengisian lembar hasil radiologi dapat berpengaruh terhadap pelayanan rekam medis dalam hal penegakan diagnosis secara tepat. Dengan lengkapnya pengisian lembar radiologi juga dapat menjadi penunjang dalam kelancaran penggunaan rekam medis dalam aspek pendidikan, karna rekam medis dapat memuat kronologis penyakit yang diderita pasien dari awal perawatan hingga selesai.

Persentase pengisian data hasil penunjang pada item konsultasi gizi yaitu pengisian sebesar 2,3\%, pengisian tidak terisi sebesar $0 \%$,dan tidak berlaku sebesar 97,6\%. Dalam hal ini pelengkapan pengisian hasil pemeriksaan penunjang sudah baik, pentingnya pelengkapan pengisian lembar konsultasi gizi juga harus di pertahankan karna. Tujuan rekam medis adalah menunjang tercapainya tertib administrasi dalam rangka upaya peningkatan pelayanan kesehatan di rumah sakit[6]. Berdasarkan hasil penelitian yang dilakukan, maka jumlah data hasil penunjang yang lengkap adalah $32,13 \%$, tidak lengkap $8,5 \%$. dan tidak berlaku $59,37 \%$ Ketidaklengkapan pengisian hal ini tentu saja tidak sesuai dengan aturan yang ada yakni. Rumah sakit dalam menganalisis rekam medis dilakukan dengan cara menelititi rekam medis yang dihasilkan oleh staf medis dan paramedic sarta hasil,hasil pemeriksaan dari unit-unit penunjang sehingga kebenaran penempatan diagnose dan kelengkapan rekam medsi dapat dipertanggungjawabkan[7]. Aturan tersebut juga diperkuat dengan Permenkes RI yaitu pembuatan rekam medis dilaksanakan melalui pencatatan dan pendokumentasian hasil pemeriksaan, pengobatan, tindakan, dan pelayanan lain yang telah diberikan kepada pasien[2].

\section{KESIMPULAN}

Berdasarkan penelitian yang dilakukan di RSUD patut patuh patju, masih terdapat ketidaklengkapan data administratif pada formulir persetujuan rawat inap $15,17 \%$, data klinis pada formulir resume medis sebesar $22,0 \%$ dan data hasil penunjang sebesar $8,5 \%$. Secara keseluruhan kelengkapan berkas rekam medis pasien rawat inap di RSUD Patut Patuh Patju belum bisa mencapai $100 \%$.

\section{DAFTAR PUSTAKA}

[1] Permenkes RI No.55/MENKES/PER/2013.

Tentang penyelenggaraan pekerjaan Perekam Medis.

[2] Permenkes RI No.269/MENKES/PER/III/2008.

Tentang rekam medis.

[3] Dirjen Yanmed Departemen Kesehatan RI. 2006. Pedoman pengelolaan Rekam Medis Rumah Sakit di Indonesia. Jakarta: DepKes.2006.

[4] Shofari,B. 2002. PSRK 01 pengelolaan Rekam Medis dan dokumentasi Rekam Medis: PORMIKI.

[5] Husen Umar. 1999. Riset Pemasaran dan Perilaku Konsumen, Cetakan Ketiga, Jakarta:PT.Gramedia Pustaka Utama.

[6] Hatta, Gemala. 2010. Pedoman manajemen informasi kesehatan disarana pelayanan kesehatan, hal 201, Jakarta:universitas Indonesia.

[7] Dirjen Yanmed Departemen Kesehatan RI. 1997. Pedoman Pengelolaan Rekam Medis Rumah Sakit Di Indonesia. Jakarta: Departemen Kesehatan Republik Indonesia. 